\title{
Host Range, Biology, and Factors Affecting Survival and Reproduction of the Stubby Root Nematode ${ }^{1}$
}

\author{
Alejandro Ayala, M.W. Allen, and E. M. Noffinger ${ }^{2}$

\section{INTRODUCTION AND REVIEW OF LITERATURE}

The genus Trichodorus was proposed by Cobb in $1913(9)^{3}$, but the importance of the species assigned as plant pathogens was not recognized until 1951 (8). Allen revised the genus in 1957 (2) adding 10 new species. Among these, T. christiei has been considered the most important economically and thus received most attention by investigators. Feeding habits of this nematode species have been investigated by Christie and Perry ( 8$)$, Rohde and Jenkins (33,34), Zuckerman $(45,46)$, and Standifer and Perry (39), and reviewed by Mountain ( 80 ). It is an ectoparasite; its head rarely becomes embedded in or attached to the roots. Cells of the host apparently are punctured by rasping motions of the stylet rather than by direct thrusts. Feeding takes place at the root tip and mechanical damage appears to be slight. Rohde and Jenkins (83), Standifer and Perry (89), and Zuckerman $(46)$ noted that the nematode may stimulate cell division in the pericycle, resulting in flattened and abnormally enlarged rootlets. Zuckerman (45) stated that there is an indication sometimes, in the swollen root tips, that one or more adventitious root laterals had been stimulated into temporary growth.

The host range of $T$. christiei has been investigated intensively by Rohde and Jenkins (39,34), Coursen, Rohde, and Jenkins (10), and Christie (7). Pathogenesis of this species has been studied on celery (40), tomato (83), onion (13), grapefruit (39), alfalfa (42), and St. Augustine grass (35). Some other species of Trichodorus also have been the subject of pathogenetic studies. Jenson (15) and Jenson and Konicek (16) concluded that T. allius is an important pest of onion in Oregon, and Rhoades (86) found T. obscurus Allen, 1957 involved in a disease of St. Augustine grass in Florida.

Limited research has been performed on the ecological factors affecting Trichodorus spp. Kirkpatrick, Van Gundy, and Mai (18) reported that in avocado seedling rootstocks planted in soil naturally infested with $T$.

1 Second portion of dissertation submitted in partial fulfillment of the requirements for the degree of Doctor of Philosophy in Nematology at the University of California, Davis.

${ }^{2}$ Associate Nematologist, Agricultural Experiment Station, Mayagüez Campus, University of Puerto Rico, Rio Piedras, P.R.; Professor of Nematology, and Laboratory Technician at the University of California, Davis, respectively.

Italic numbers in parentheses refer to Literature Cited, pp. 367-9. 
christiei, the population levels of the nematode were negatively associated with root vigor. Fertilizer applications were consistently associated with a decrease in the number of $T$. christiei, per pint of soil, and the percentage of parasitized root tips, while root growth continued to increase. Van Gundy et al. (43) reported T. christiei to be more sensitive to length of exposure to oxygen than any of the other species used. Bird and Mai (6) found morphometric differences in a population of T. christiei in relation to the host plant used. In 1965, Malek, Jenkins, and Powers (26) found optimum temperature for $T$. christiei was close to $25^{\circ} \mathrm{C}$.

Since 1958, when Hewitt, Raski, and Goheen (12) demonstrated that nematodes are vectors of plant viruses, efforts have been made to develop a better understanding of the factors affecting survival of nematode vectors in the soil. Very little in this regard has been accomplished with Trichodorus spp. Studies with species of this genus have been concentrated on the discovery of new species as vectors of the viruses causing tobacco rattle and pea early browning. The present investigation was initiated in 1962 and conducted in relation to transmission of California tobacco rattle virus (CTRV). It was intended to throw more light on virus-vector interrelationships. Four factors were studied; limited investigations were made on the biology of T. allius; and the host range was explored of three species of Trichodorus.

\section{MATERIALS AND METHODS}

All host range studies were conducted under ambient greenhouse temperatures, except for the last trial with $T$. allius, which was carried out in a temperature-controlled tank at $24^{\circ} \pm 2^{\circ} \mathrm{C}$. Seeds were germinated directly in 4-inch clay pots, or seedlings were transplanted from seed beds. After extraction, the nematode concentration was calculated by counting four or five aliquots of $1 \mathrm{ml}$. each. Dilutions were made accordingly and 100 nematodes were pipetted into each 5 -inch pot containing sterilized soil or a mixture of this and coarse sand (ratio of $1: 3$ ) in the case of T. allius. Two checks were always included, e.g., the best host plant known for each nematode species and fallow soil. Inoculated plants were usually allowed to grow 6 to 8 weeks after which the nematodes were recovered and populations assessed. Each plant species was then classified as nonhost, no nematodes recovered or occurring less than in soil without a host; poor host, no increase over number added; good host, increase over 1 to 10 times; excellent host, an increase of over 10 times.

Conditions were varied in studies conducted on the effects of some ecological factors on nematode populations, but in general the above conditions prevailed. Effect of temperature was studied in a series of tanks with adjustable temperature controls. The same tanks were used to study fertilizer 
concentrations, although a greenhouse bench was used in the case of $T$. christiei. Different dilutions, with water, were prepared from Hoagland's solution which served as the stock for the fertilizer. To study the effects of different soil types, mixtures of different concentrations of greenhouse potting soil, coarse sand, and white quartz sand were prepared using a small rotatory mixer.

Attempts were made to study the biology of $T$. allius under monoxenic conditions. For this, sweetpea seeds were first soaked 2 to 3 hours in running tap water in a small bag made of cheesecloth. The seeds were transferred to 10-percent Clorox for 20 minutes, rinsed 3 times in sterile glass distilled water, and finally placed on petri dishes containing agar. A 1.5-percent water agar was used to which iron, Knop stock solution, and Bertholot stock had been added. The seeds were then allowed to germinate in the dark at $25^{\circ} \mathrm{C}$.

A population of $T$. allius was axenized at the same time by means of a modified Lownsbery and Lownsbery apparatus (22). Nematodes were kept in a humidified air chamber for 24 hours, then centrifuged and added to the top tube containing Aretan. The tube was then capped with aluminum foil. A flow of sterile air was introduced into the tube containing the nematode suspension and Aretan by puncturing the aluminum cap and inserting a glass tube connected to an air sterilizer. The air supply was removed after 12 to 18 hours, the tube capped with another aluminum cap, and the nematodes allowed to settle for $\mathbf{4 5}$ minutes. The nematodes were then dropped into the middle tube containing nutrient solution and allowed to settle for 20 minutes. Axenized nematodes were then introduced into the germinated seed cultures by a previously sterilized bamboo needle or a sterile syringe. In other experiments, nematodes were washed with distilled water 4 times and added to sweetpea roots, 10 to $15 \mathrm{~cm}$. long, without axenization.

Nematodes from field samples and greenhouse cultures were extracted from soil and roots by a combination of Cobb's screening and Baermann funnel methods; at times a modified Seinhorst mist chamber was used. Unless otherwise indicated only two screens were used: The 60-mesh to separate large debris, plant and root materials, and the 200 - or 325-mesh for recovering nematodes. The 200-mesh screen was used to isolate nematodes to be used in experiments, while the 325-mesh screen was used for more critical recovery of nematodes from transmission and other experiments.

The procedure used with the Baermann funnel method depended on the species of Trichodorus involved, and the purpose of the nematode recovery. Nematodes not to be used in further experiments were left in the funnels for 3 days, then recovered and counted. When nematodes were to be used 
in experiments, the samples were counted after 24 hours in the case of $T$. christici and T. porosus, or every 3 hours for 3 days in the case of T. allius. Since nematodes of the latter species survived only short periods of time in unoxygenated water, they were used immediately after recovery or were placed in a humidity air chamber as described below. In no case were nematodes used for biological experiments if they had been removed from the soil for more than 24 hours. Other modifications were made according

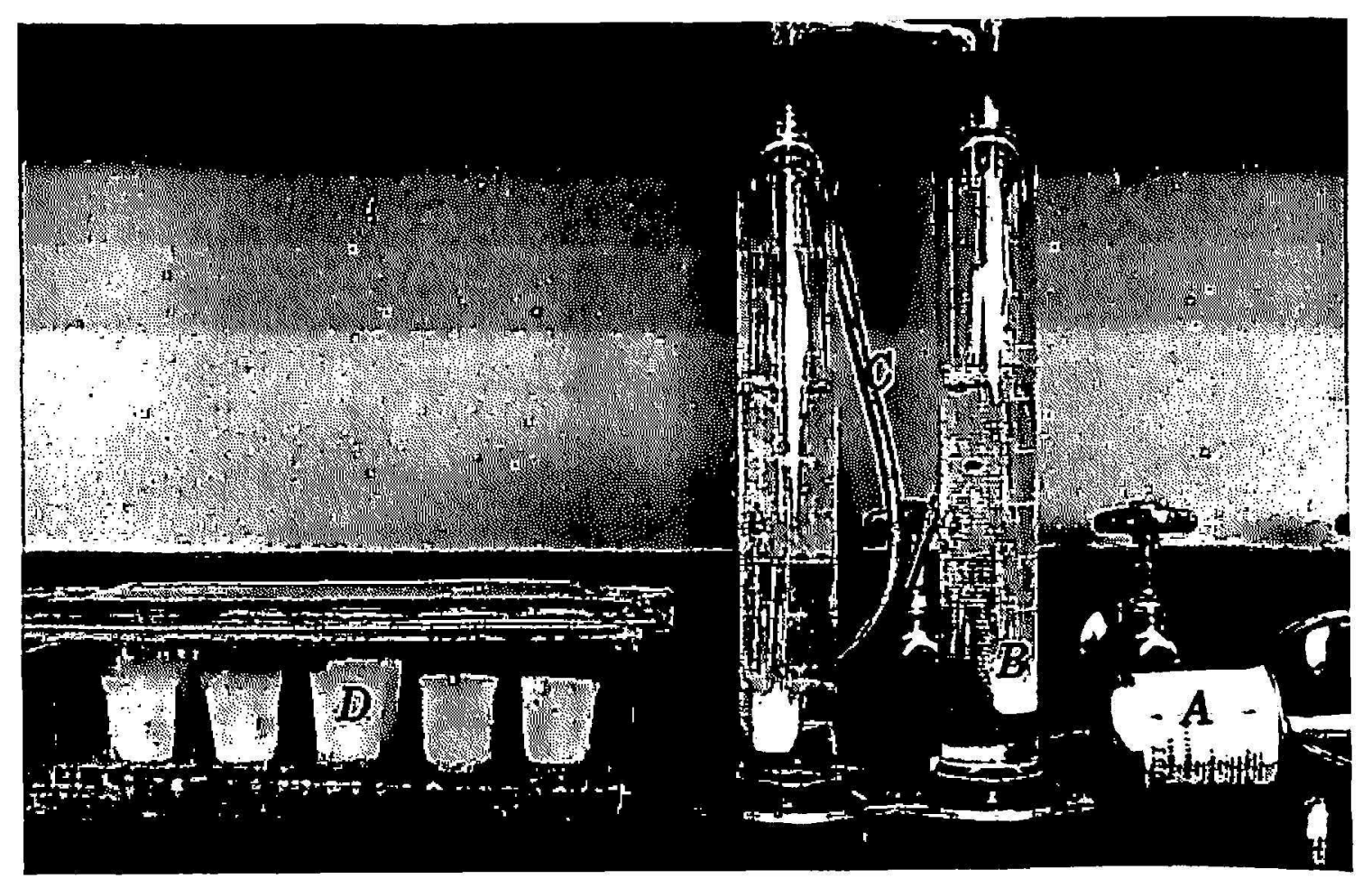

Frg. 1.-Humidity air chamber used for maintaining $T$. allius populations alive for long periods of time. A, Air purifier. B, Fritted glass, gas dispersion tubes. C, 25 cm. columns of water. D, Plastic chamber containing distilled water, large mesh screen and plastic cups $(50 \mathrm{cc}$.) with nematode suspension.

to the purpose of the experiment and details are given in the appropriate section.

A humidified air chamber (fig. 1, A-D) was used to store live populations of Trichodorus allius for long periods of time. In principle, the apparatus consisted of two fritted glass, gas dispersion tubes through which purified air was passed into two columns of water and finally into a chamber made of plastic material. The air flow was regulated to the desired pressure and purified with a Koby air purifier (A) connected by a plastic tube $1 \mathrm{~cm}$. in diameter to a flow equalizer. A plastic or rubber tube connected the air purifier to the first of two fritted glass, gas dispersion tubes (B) placed at the bottom of two $25 \mathrm{~cm}$. columns of water (C). The first column of water was connected to the second by a rubber tube $5 \mathrm{~cm}$. long inserted over glass 
tubes extending from above the first column of water and from the second gas dispenser. Two perforated rubber stoppers connected the different tubes at the tops of both columns. A bent glass tube inserted into the rubber stopper in the second water column provided the outlet for the humidified air which was blown into the air chamber (D) through a rubber tube 50 $\mathrm{cm}$. long and $1 \mathrm{~cm}$. in diameter. A glass tube was inserted and glued in a hole at one end of the plastic box. Two pieces of hard rubber tube provided further support for the glass tube. The chamber consisted of a plastic box $30 \mathrm{~cm}$. long, $27 \mathrm{~cm}$. wide, and $10 \mathrm{~cm}$. high, with a slip-in lid. The bottom of the box was covered to a depth of $2 \mathrm{~cm}$. with tap or distilled water. A coarse mesh metal screen provided support for the containers with nematodes to prevent contact with the water. The lid was sealed with Vaseline to restrict evaporation and contamination. A glass tube was inserted in a hole at the opposite end of the box and provided the outlet for gases. This tube was plugged with cotton to prevent contamination. Containers up to a size of $200 \mathrm{cc}$. beakers with nematodes in water, sand or soil could be stored for long periods of time at ambient temperatures of $24^{\circ} \mathrm{C}$.

\section{RESULTS AND OBSERVATIONS}

\section{FACTORS AFFECTING SURVIVAL AND REPRODUCTION OF TRICHODORUS SPP.}

\section{Temperature}

The effect of temperature was studied on the survival and reproduction of three species of Trichodorus in experiments conducted at temperatures ranging form $10^{\circ}$ to $35^{\circ} \mathrm{C}$. in controlled temperature water baths. The original nematode inoculum was 100 nematodes pipetted into each clay pot containing the indicated hosts in sterilized soil. The experiments were of 8 weeks duration and all sweet corn plants (Zea mays L. var Improved Bantam Early) received 50 percent Hoagland's nutrient solution each day as needed. Each treatment was replicated 5 times.

Trichodorus porosus and the two isolates of $T$. christici reproduced on sweet corn at all temperatures tested, e.g. $12^{\circ}$ to $29^{\circ} \mathrm{C}$. and at greenhouse ambient temperatures (fig. 2). Populations of T. porosus increased linearly up to a peak at $24^{\circ} \mathrm{C}$. with a sudden decrease at $29^{\circ} \mathrm{C}$. The optimum temperature was $24^{\circ} \mathrm{C}$, being highly significant over all others. The optimum temperature for plant growth appeared to be around $20^{\circ} \mathrm{C}$. At $24^{\circ} \mathrm{C}$. the weight of the plants decreased considerably more than at higher temperatures of $29^{\circ} \mathrm{C}$., which may suggest there is a detrimental effect of the nematode on plant vigor.

Two isolates of T. christiei behaved similarly at different temperatures and both were able to reproduce at all test temperatures (fig. 3). The opti- 
mum in both cases seemed to be between $16^{\circ}$ and $20^{\circ} \mathrm{C}$. The cause for the presence of these two peaks or for the drop at $20^{\circ} \mathrm{C}$. is not understood. Populations of the Riverside isolate increased better at variable tempera-

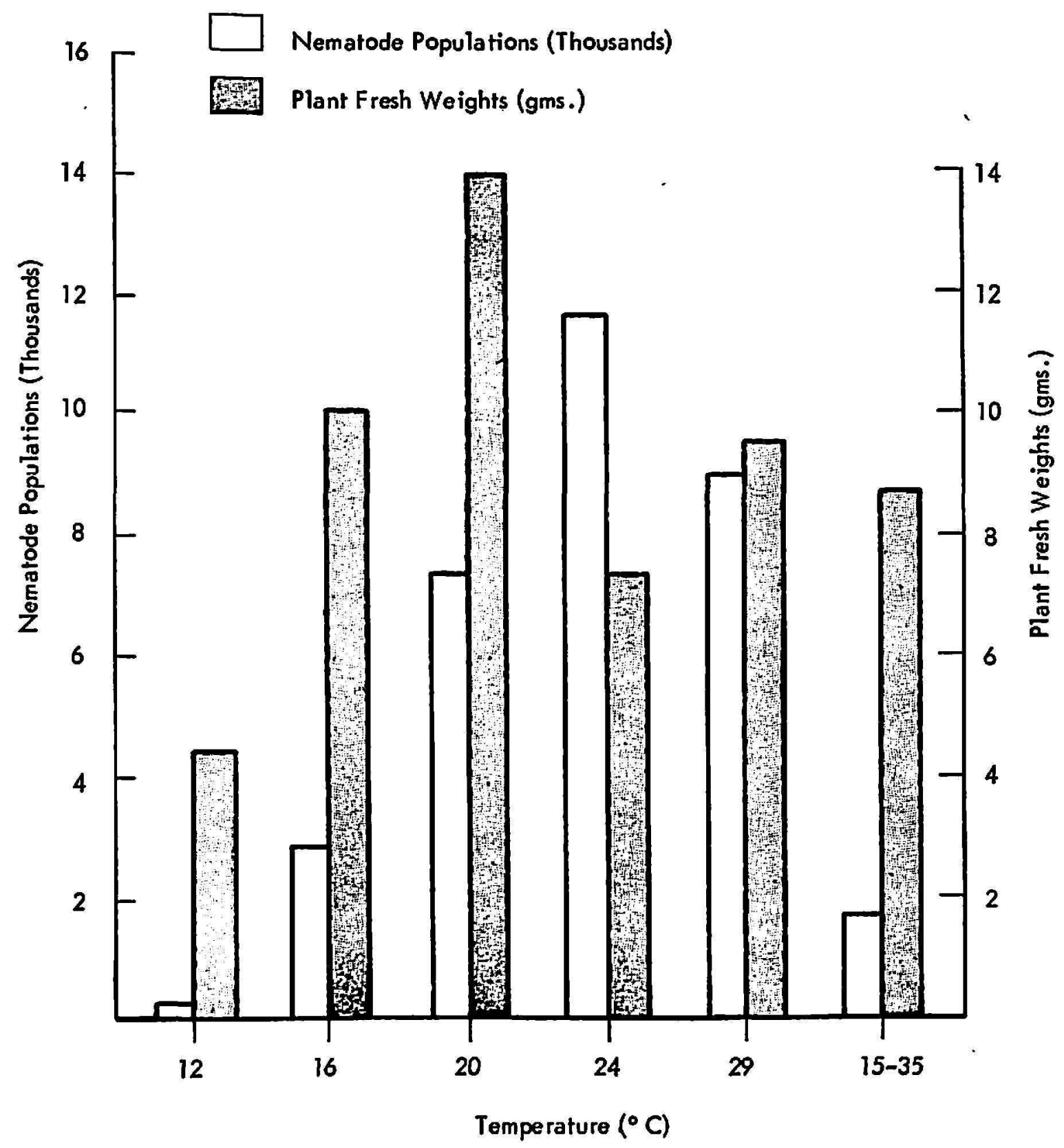

Fra. 2.-Effect of temperature on population increase of Trichodorus porosus.

tures than the Shafter isolate, whereas the opposite was true at all other temperatures.

Effect of temperature on the reproduction and population increase of $T$. allius was studied in 5-inch clay pots and on two different host plants. In the first experiment cotton served as the host plant. Nematode populations increased only at $21^{\circ}$ and $26^{\circ} \mathrm{C}$. (fig. 4) and differences between these 
two treatments were significant. Differences also were significant between these two treatments and all others, while there were no significant differences among the other treatments. The cotton root system did not develop at the lower temperature, and the plants remained stunted and chlorotic. More growth occurred at higher temperatures, particularly $29^{\circ} \mathrm{C}$. In a second experiment with $T$. allius, 5 -day-old sweetpea Floribunda mixed

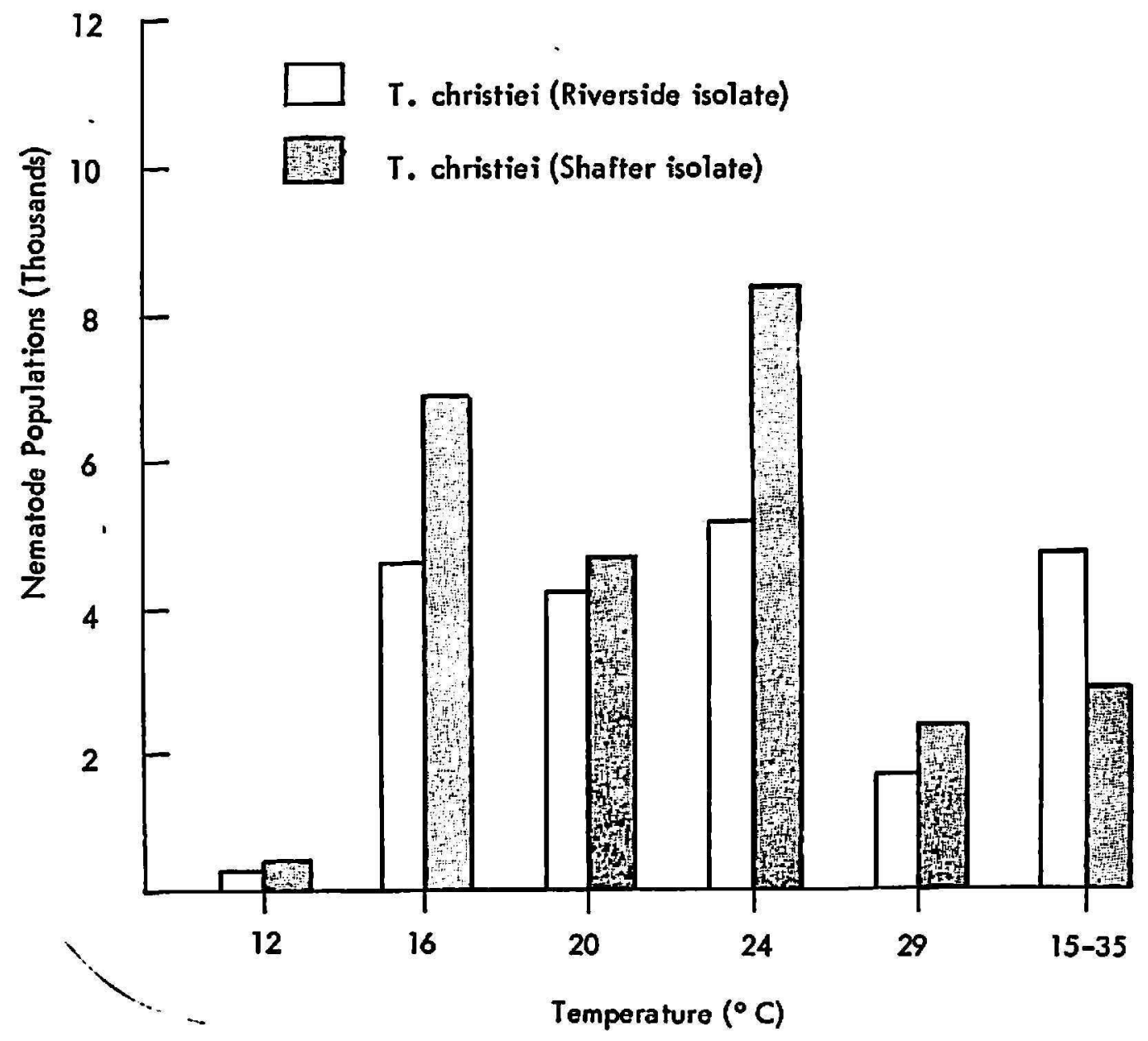

Fia. 3.-Effect of soil temperature on the reproduction of two isolates of $T$. christici.

variety plants were used as the host plant. The highest populations were recovered from plants grown between $21^{\circ}$ and $24^{\circ} \mathrm{C}$. (fig. 5) with the best increase at $21^{\circ} \mathrm{C}$. The nematodes reproduced at $18^{\circ}$ and $29^{\circ} \mathrm{C}$. but populations remained low, varied considerably among replicates, and were not significantly different. Sweetpea grew well at all temperatures and was a good host for this nematode.

\section{Soil Type}

The effect of soil type on reproduction and population increase of $T$. allius was studied in combination with a transmission experiment, in a 
growth chamber. Table 1 shows that the nematodes reproduced best in media containing the following ratios of coarse sand, white pearl sand, and and greenhouse potting soil: 1:2:1, 3:0:1, and 2:1:1. No significant differences were evident among these treatments, but these were significantly different from all other treatments. Very low population increases resulted when each of the original mixing media was used alone or when

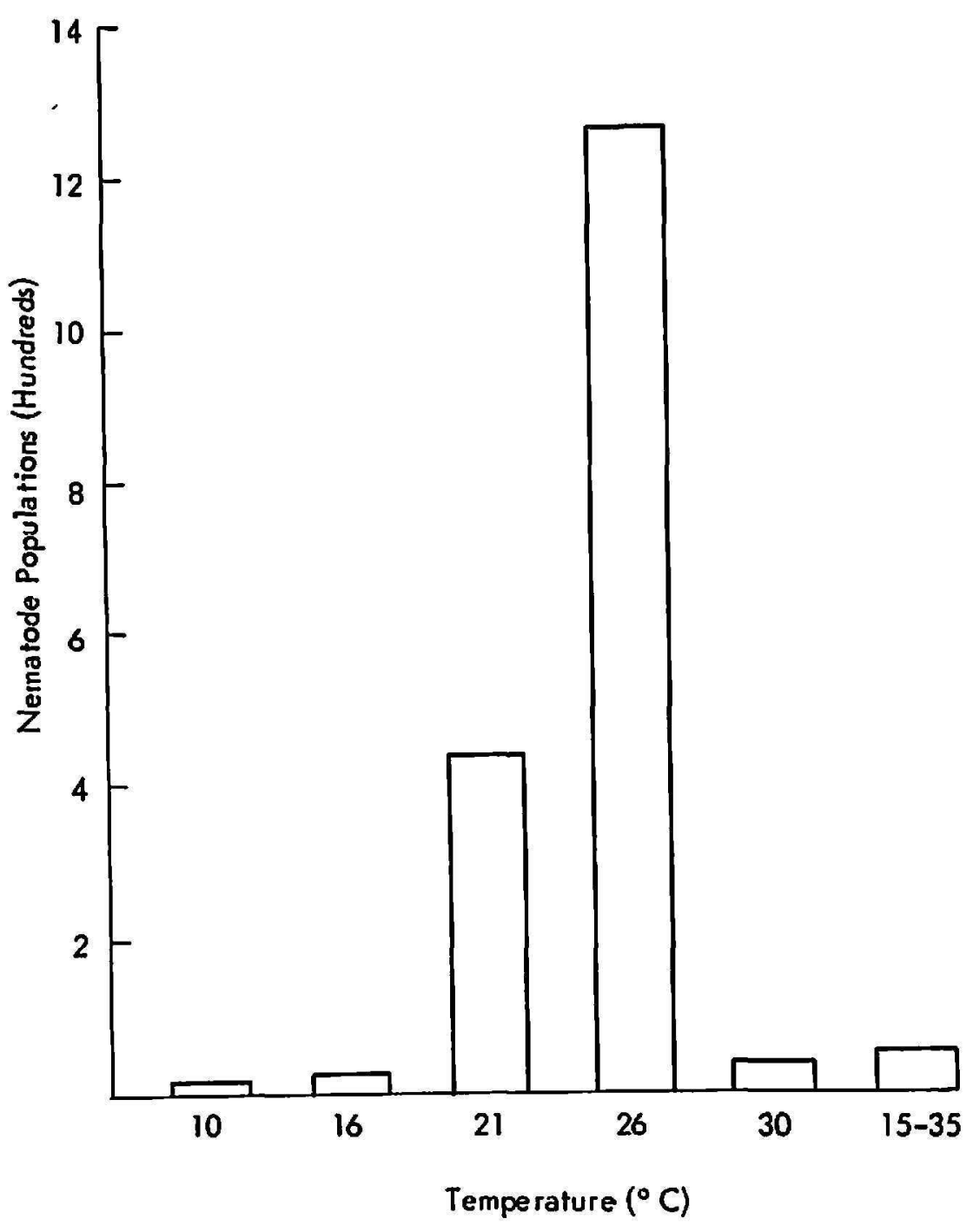

FIG. 4. Mean populations of T.allius per 500 cc. of soil in relation to soil temperature.

soil was excluded from the mixtures. All treatments containing a combination of soil with any of the sands resulted in good nematode population increase, except for onc treatment containing 50 percent soil and 50 percent white sand.

Effect of Fertilizer Concentrations

Effect of fertilizer applications was studied on the reproduction and population increase of $T$. christici and $T$. allius by addition of different 
dilutions of Hoagland's nutrient solution to pots containing nematodes and sweet corn and sweetpea plants, respectively. Sweet corn seeds of the variety Improved Bantam Early served as the test plant for T. christiei. All treatments were replicated 5 times and the initial inoculum consisted of 150 nematodes per pot.

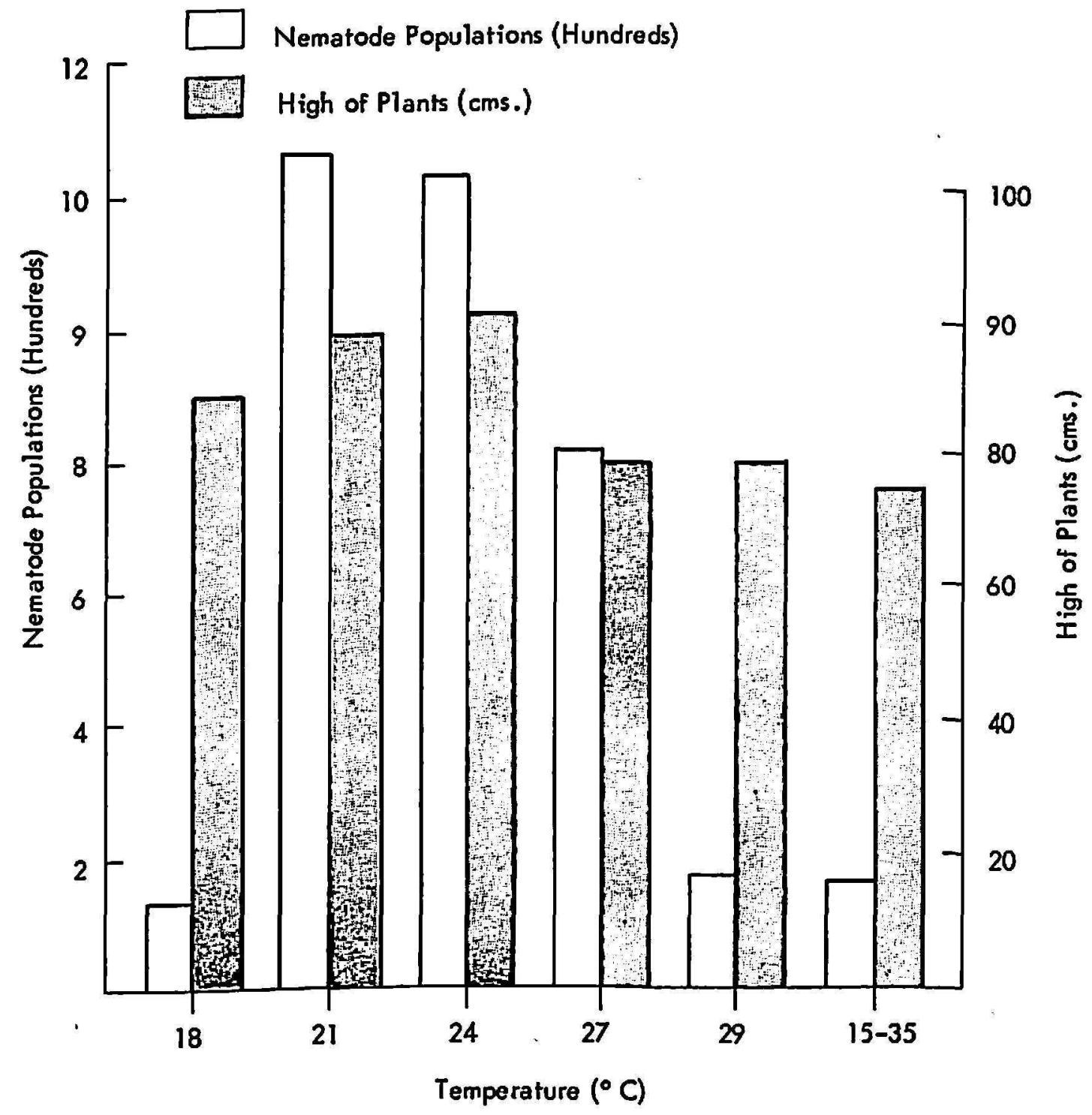

Fig. 5.-Mean populations of T. allius per 500 cc. of soil and sweetpea growth in relation to soil temperature.

Daily applications of 50-percent Hoagland's nutrient solution provided the best conditions for nematode reproduction or population increase (fig. 6). Results as to nematode population increases from this treatment were highly significant over the remaining treatments. Those plants receiving applications of water or 100-percent Hoagland's nutrient solution alone (every day) supported the lowest nematode population increase. The nematode population increased with higher concentrations of fertilizer up 
to 50 percent, but then decreased at the higher fertilizer level. Plant fresh weight, height, and general appearance increased with the higher fertilizer concentrations.

At the 100-percent level of fertilizer, nematode populations remained at the same level as when water alone was added. The plants grew more vigorously at 100-percent solution concentration while corn plants recieving plain water appeared chlorotic, stunted and very poor root systems developed. The plants receiving one or two applications of Hoagland's nutrient solution per week reacted similarly. No significant differences were detected between the plants receiving one or two applications of

TABLE 1.-Nemalode population increase in differenl artificial soil types in a growth chamber

\begin{tabular}{c|c|c|c|c}
\hline \multicolumn{3}{c|}{ Combination rates } & \multicolumn{2}{c}{ Number of nematodes } \\
\hline Soil & White sand & Coarse sand & Initial & Recovered \\
\cline { 1 - 2 } Percent & Percent & Percent & & Mean \\
50 & 25 & 25 & 25 & 83 \\
25 & 50 & 25 & 25 & 145 \\
25 & 25 & 50 & 25 & 119 \\
100 & - & - & 25 & 37 \\
- & 100 & - & 25 & 25 \\
- & - & 100 & 25 & 37 \\
50 & 50 & - & 25 & 91 \\
50 & - & 50 & 25 & 54 \\
- & 50 & 50 & 25 & 73 \\
- & 25 & 75 & 25 & 43 \\
25 & - & 75 & 25 & 126 \\
25 & 75 & - & 25 & 89 \\
\hline
\end{tabular}

fertilizers per week but differences were highly significant between them and daily applications of pure Hoagland's solution, which suggests there could be a detrimental effect of fertilizer concentrations against the nematode.

Fertilizer concentration was studied with $T$. allius under controlled conditions of temperature in a water bath at $24^{\circ} \mathrm{C}$. In this experiment 1week old sweetpea seedlings were used as the test plant and the initial inoculum consisted of $24 \pm 1$ nematodes per 3 -inch clay pot.

Two months after inoculation, nematode populations were high in all treatments and there was no marked effect of fertilizer on nematode reproduction (table 2). Dry and fresh plant and root weights, and length of stems did not reveal significant differences, but the plants in general appearance varied with the treatment; at lower levels of fertilizer, plants 
appeared chlorotic. Applications of Hoagland's solution to all the pots before inoculating with nematodes was sufficient to provide the necessary nutrients for plant growth and nematode reproduction. Although differences in plant appearances were evident after applications of the indicated

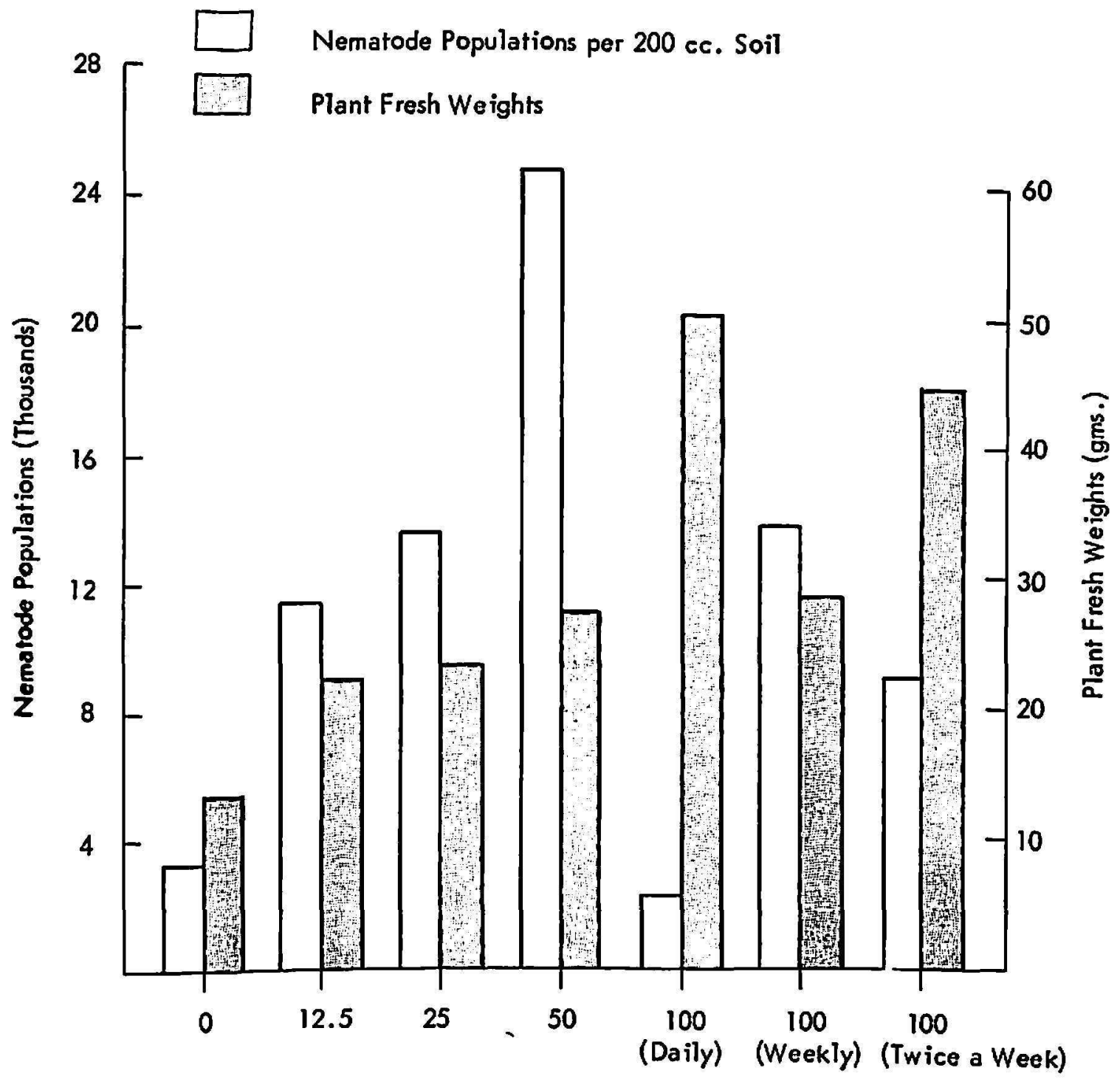

Fertilizer Concentration (\%)

FIG. 6. Populations of $T$. christiei and sweet corn plants fresh weights in soil receiving different concentrations of Hogland's nutrient solution for 8 weeks.

concentrations of fertilizer, these did not appear to exert much effect on nematode reproduction.

"Swollen cuticle" Condition of T. christiei

A condition or abnormality designated here as "swollen cuticle", was repeatedly observed in a population of $T$. christiei (Riverside isolate) originally obtained from spinach and cultured in sweet corn. This abnor- 
mality is characterized by a solid mass of unidentified nature between the cuticle and hypodermis, usually on the ventral side immediately anterior to the anal region (fig. 7, A). Occasionally it occurred laterally or dorsally and in any position on the nematode up to the vulval region (fig. 7, B). In formalin-fixed specimens the mass appeared yellowish and stained deeper and faster in ethylene blue than the other nematode tissue. At times, up to S5 percent of a population carried the condition in different degrees. It was more pronounced in the fourth stage larvae and adult females. It was first thought to be an indication of CTRV infectivity, but non-viruliferous populations also were affected. It is not an indication of the beginning of molting because even egg-carrying females were affected. Moreover, the condition seemed to become more pronounced with the age of the

TABLE 2.-Reproduction of Trichodorus allius on sweelpea roots receiving differenl concentrations of Hoagland's nutrient solution

\begin{tabular}{|c|c|c|c|c|}
\hline \multirow{2}{*}{$\begin{array}{l}\text { Concentration of Hoagland's } \\
\text { nutrient solution }\end{array}$} & \multicolumn{2}{|c|}{ Nematode population } & \multirow{2}{*}{$\begin{array}{c}\text { Plant dry } \\
\text { weights }\end{array}$} & \multirow{2}{*}{$\begin{array}{c}\text { Length of } \\
\text { stem }\end{array}$} \\
\hline & Initial & Final & & \\
\hline $\begin{array}{l}\quad \text { Pcrcent } \\
0 \\
12.5 \\
25 \\
50 \\
75 \\
87.5 \\
100 \\
100 \text { twice a week }\end{array}$ & $\begin{array}{l}24 \pm 1 \\
24 \pm 1 \\
24 \pm 1 \\
24 \pm 1 \\
24 \pm 1 \\
24 \pm 1 \\
24 \pm 1 \\
24 \pm 1\end{array}$ & $\begin{array}{l}5,507 \\
3,859 \\
5,240 \\
4,299 \\
3,199 \\
3,593 \\
2,933 \\
5,155\end{array}$ & $\begin{array}{r}\text { IIg. } \\
846 \\
890 \\
932 \\
896 \\
1102 \\
950 \\
1216 \\
746\end{array}$ & $\begin{array}{c}\mathrm{Cm} . \\
63.8 \\
72.8 \\
71.4 \\
76.8 \\
66.6 \\
74.2 \\
72.4 \\
65.8\end{array}$ \\
\hline
\end{tabular}

nematode and females with large "masses" appeared transparent and sluggish in water as compared to the dark, active, healthy members of the same population.

Investigations were conducted to see if this "swollen cuticle" condition might affect the fertility of the nematode or if it was inherited. An experiment was designed using two separate hosts. An original population containing a high percentage of "abnormal" nematodes were added, in groups of 10 , to alfalfa and sweet corn in 4-inch clay pots with sterile soil.

Two months after inoculation, high numbers of nematodes were recovered from both populations maintained on either host. Sixty seven percent of the progeny from the abnormal populations were swollen-tailed; abnormal individuals were also recovered from originally normal populations in one occasion. This suggests that a nematode may be a carrier of the condition without showing it in the earlier stages of development. 


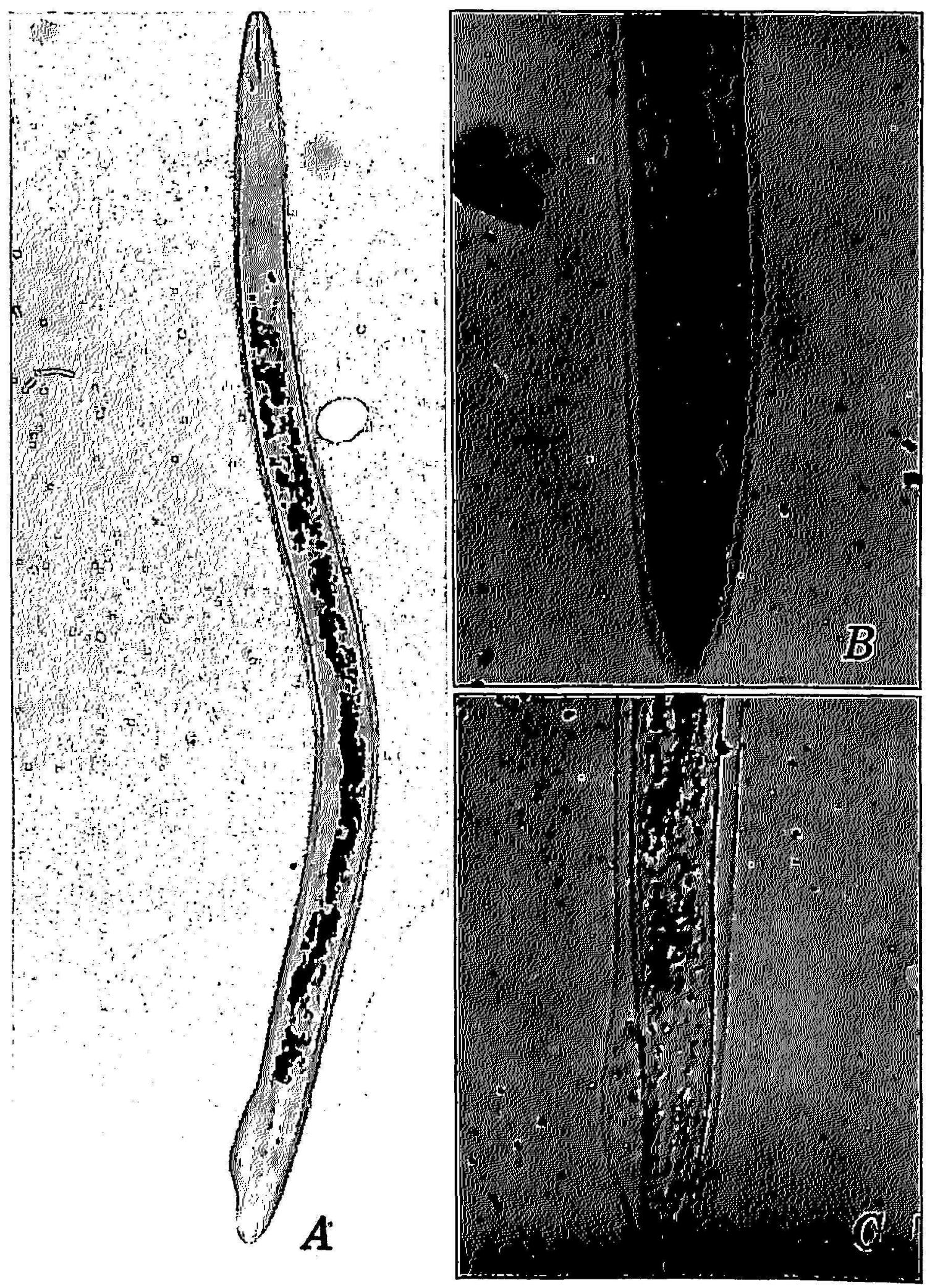

Fia. 7.-A, Trichodorus christiei. Stained specimen showing "swollen" cuticle condition. B, Posterior portion of normal female stained in ethylene blue (10 p.p.m.) for 1 hour. C, Stained female posterior portion showing advanced swelling of the cuticle on ventral side. 


\section{Possible Effects of C'TRV on its Nematode Vector}

Observations made during transmission and host range experiments indicated that virus-infected tobacco plants supported higher populations of $T$. allius than "healthy" plants. This suggests a possible alteration of the suitability of the plant to nematode feeding has occurred or an increase in the reproduction rate of viruliferous nematodes has taken place. An experiment was conducted in 4-inch clay pots containing a coarse sand-soil mixture (ratio of $3: 1$ ). Three treatments, replicated 8 times, were included, i.e. 1, no host (fallow); 2, 1-month-old Glurk tobacco plants

TABLE 3.-Reproduction of Trichodorus allius uhile feeding on virus-infecled and virus-free Glurk tobacco plants, and survival without a host

\begin{tabular}{c|c|c|c}
\hline \multirow{2}{*}{ Replicate } & \multicolumn{3}{|c}{ Number of nematodes in each treatment } \\
\cline { 2 - 4 } & Virus-infested host & Virus-free host & No host \\
\hline 1 & 907 & 178 & 6 \\
2 & 4,763 & 198 & 14 \\
3 & 2,826 & 279 & 15 \\
4 & 1,782 & 270 & 13 \\
5 & 1,053 & 279 & 14 \\
6 & 999 & 72 & 8 \\
7 & 2,190 & 45 & 15 \\
8 & 228 & 549 & 19 \\
\hline Means & $1,841 \pm 507$ & $234 \pm 34$ & $13 \pm 2$ \\
\hline LSD at .05 & \multicolumn{3}{|c|}{1,091} \\
LSD at .01 & \multicolumn{2}{|c}{1,519} & 260 \\
\hline
\end{tabular}

1 The original inoculum consisted of 56 nematodes including all developmental stages.

mechanically inoculated with CTRV; and 3, 1-month-old, "healthy" Glurk tobacco plants. The plants were of the same age, size and vigor, and each plant received applications of 50-percent Hoagland's solution before and throughout the experiment. The original inoculum consisted of $56 T$. allius of all stages.

Six weeks later, virus-infected plants supported higher populations than the healthy plants (table 3). The differences as to nematode populations recovered from these treatments were significant. Very few nematodes survived for 6 weeks in the absence of a host. The differences observed between nematode populations in fallow and virus-free plants were significant at the 5-percent level. The virus-infected plants were retarded in growth and poor in appearance. These results still do not solve the question 
whether the increase is due to an alteration of the suitability of the plant feeding or to a direct effect of the virus on the nematode.

\section{HOST RANGE OF THREE SPECIES OF TRICHODOROS}

Host range studies were conducted for $T$. christiei (Riverside isolate), $T$. porosus, and T. allius. Plant species belonging to several families numbering 50,25 and 38 species, were tested as potential hosts for the respective nematode species.

Several plant species tested are known to be hosts of $T$. christiei, but were included to study possible differences in host preference between different isolates. Many of the other plant parasitic species of nematodes are known to have strains or physiological races with distinct host preferences.

The same information that was needed for $T$. christiei was necessary for $T$. porosus and $T$. allius. Up to the present time no extensive host range studies had been made for these species. Populations of T. californicus were never high enough to obtain the large numbers needed for a host range study.

Results obtained from the host range studies are shown in tables 4, 5; and 6. The common and scientific name for each plant and their relative classification as to suitability as hosts is listed. These plants have been arranged according to families and the names checked in the Agriculture Handbook (3) and Bailey's manual (4). Nematode populations represent the means of five replicates for the first two species, and four and five in the case of $T$. allius.

It is evident that marked differences in host preference exist between $T$. christiei (Riverside isolate) and other isolates. For instance, garden peas and spinach are rated as poor hosts by Rohde and Jenkins (3S) while in these tests they were good hosts; cabbage was an excellent host for the Florida isolate while only good for the Riverside isolate; alfalfa, common bean, and corn were good hosts for the Florida isolate and excellent for the Riverside. Lycopersicon peruvianum (L.) Mill., Caliverde alfalfa, sweetpea, lettuce, and sweet corn supported the highest populations of Christie's stubby-root nematode. Among the herbaceous plants most members of the family Solanaceae, carrot, baby lima bean, cucumber, and radish are either poor or nonhosts. Woody plants such as Thompson Seedless grape, multiflora rose, Lovell peach, and wingnut proved to be reasonably good hosts, while walnuts supported very low populations.

The number of plant species tested as hosts for $T$. porosus was less than for $T$. christiei (tables 3 and 4), but enough information was gathered to support a relative comparison in host preference between the two species. Eight weeks after inoculation, Nicotiana glutinosa, upland cotton, sweet corn, and alfalfa supported populations of $T$. porosus 10 times higher than the original inoculum consisting of 100 nematodes. Lycopersicon peru- 
TabLE 4.-Plant species tested as potential hosls of T. christiei (Riverside isolate) ${ }^{1}$

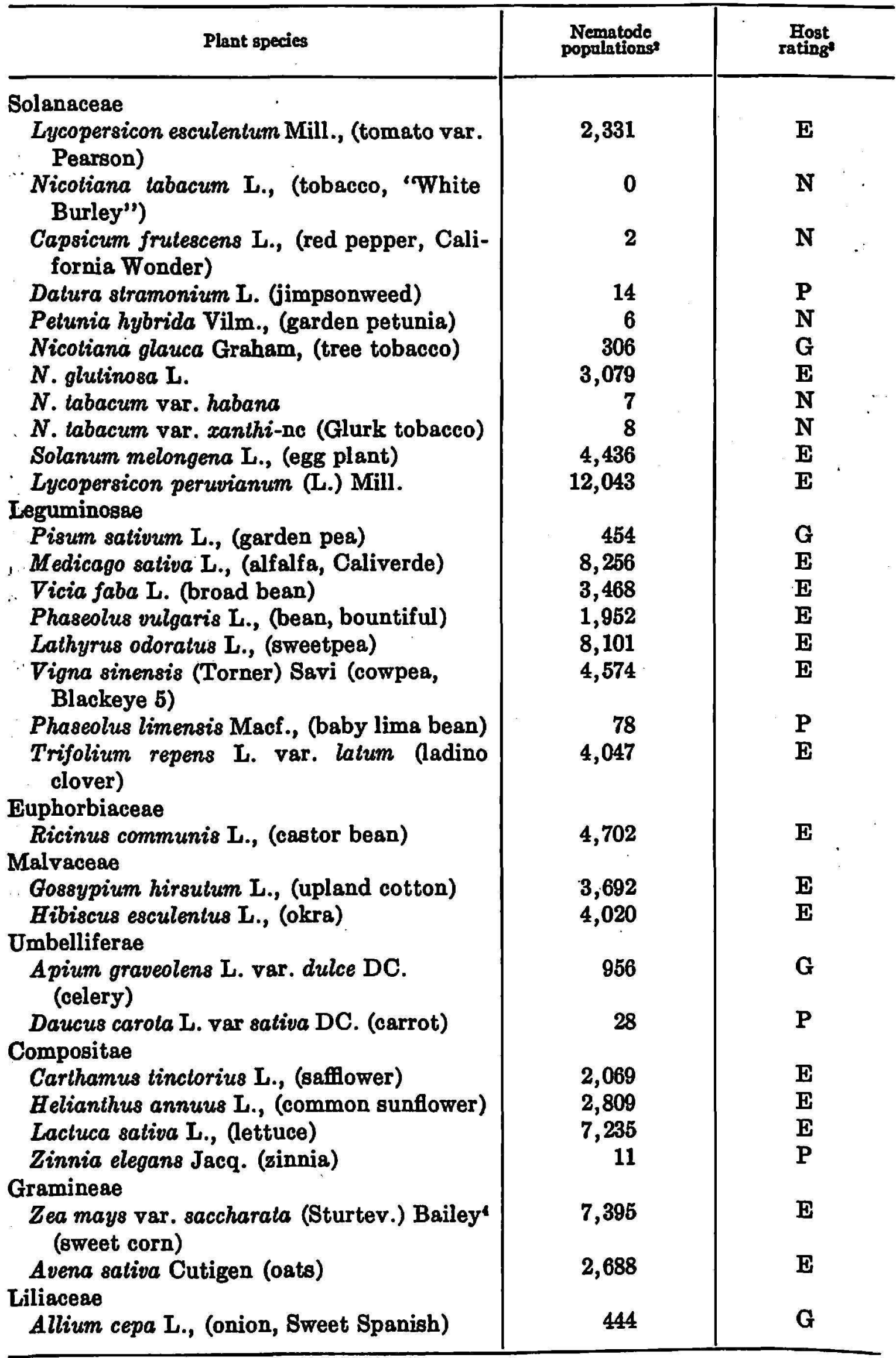


TABLE 4.-Continued

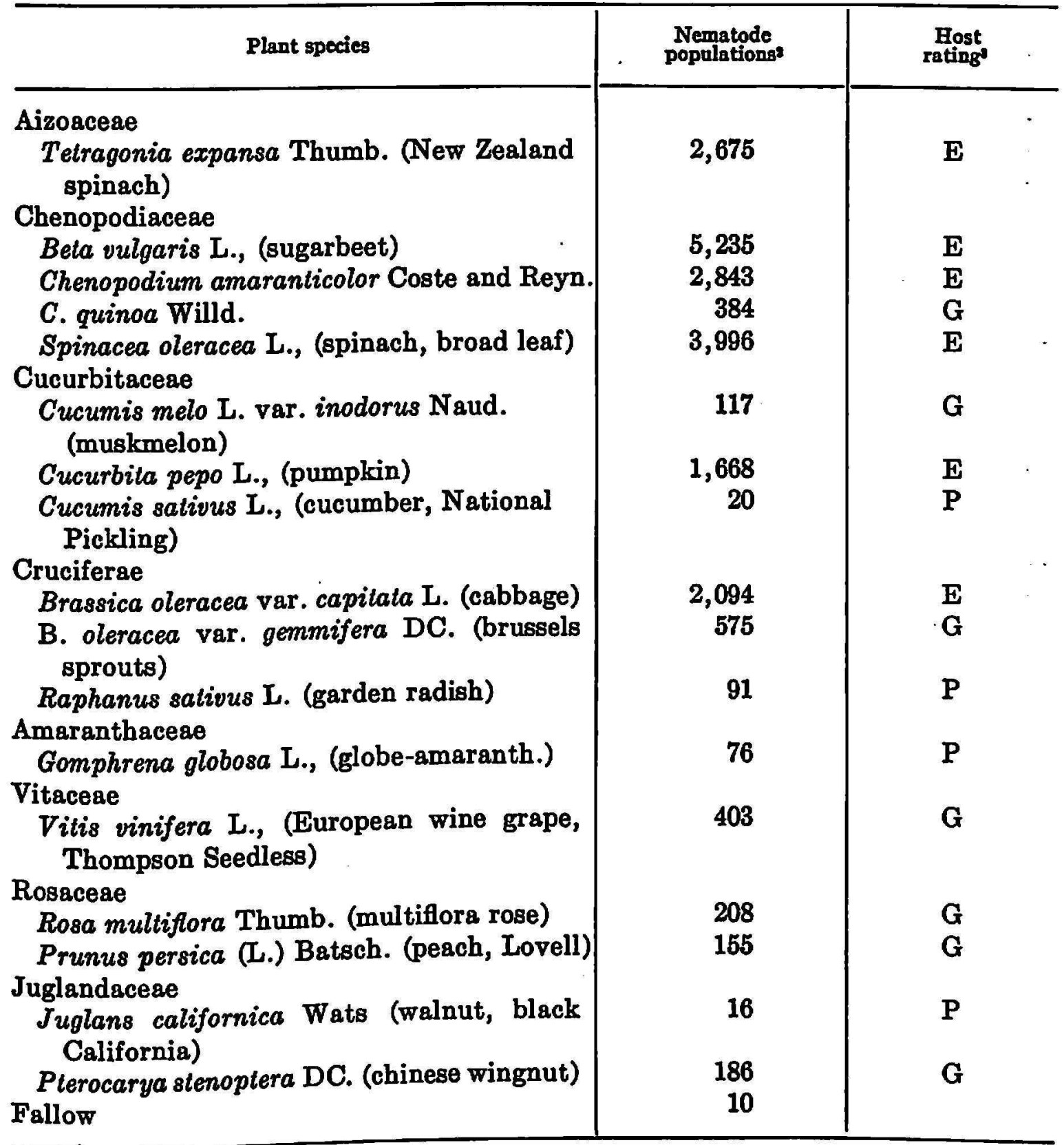

${ }^{1}$ Length of experiment: 8 weeks.

2 Represent the means of 5 replications. The original inoculum consisted of 100 specimens of all developmental stages.

Host ratings: E-excellent; G-good; P-poor; N-nonhost.

- Best host available before the experiment, based on the literature.

vianum, the best host for $T$. christiei, was only a good host for $T$. porosus. Tomato, cowpea, spinach, and lettuce were only good hosts for $T$. porosus while they were excellent hosts for T..christiei. Carrot. was a good host for $T$. porosus and poor for the Riverside isolate of T. christiei. Three species of the family Solanaceae (white burley tobacco, and pepper) proved to be nonhosts. Among the woody plants, grape, Mahaleb cherry, apple, Lovell 


\begin{tabular}{|c|c|c|}
\hline Plants species & $\begin{array}{r}\text { Nematode } \\
\text { populations? }\end{array}$ & $\begin{array}{c}\text { Host } \\
\text { rating: }\end{array}$ \\
\hline \multicolumn{3}{|l|}{ Solanaceae } \\
\hline $\begin{array}{l}\text { Nicotiana tabacum L., (tobacco, "White } \\
\text { Burley") }\end{array}$ & 3 & $\mathbf{N}$ \\
\hline N. tabacum var. xanthi-nc & 3 & $\mathbf{N}$ \\
\hline N. glutinosa $\mathbf{L}$ & 1,297 & $\mathbf{E}$ \\
\hline $\begin{array}{l}\text { Lycopersicon esculentum Mill. (tomato, } \\
\text { Pearson) }\end{array}$ & 401 & $\mathbf{G}$ \\
\hline L. peruvianum (L.) Mill. & 450 & G \\
\hline $\begin{array}{l}\text { Capsicum frutescens L., (pepper, California } \\
\text { Wonder) }\end{array}$ & 3 & $\mathbf{N}$ \\
\hline \multicolumn{3}{|l|}{ Leguminosae } \\
\hline Pisum sativum $\mathrm{L}$. (garden pea) & 244 & G \\
\hline $\begin{array}{l}\text { Vigna sinensis (Torner) Savi (cowpea, } \\
\text { Blackeye) }\end{array}$ & 347 & $\mathbf{G}$ \\
\hline Medicago sativa L., (alfalfa, Caliverde)4 & 5,718 & $\mathbf{E}$ \\
\hline $\begin{array}{l}\text { Malvaceae } \\
\quad \text { Gossypium hirsutum L., (upland cotton) }\end{array}$ & 2,442 & $\mathbf{E}$ \\
\hline \multicolumn{3}{|l|}{ Umbelliferae } \\
\hline $\begin{array}{l}\text { Daucus carota L. var. sativa DC. (carrot, } \\
\text { Imperator) }\end{array}$ & 130 & $\mathbf{G}$ \\
\hline \multicolumn{3}{|l|}{ Gramineae } \\
\hline $\begin{array}{l}\text { Zea mays var. saccharata (Sturtev.) Bailey } \\
\text { (sweet corn) }\end{array}$ & 3,900 & $\mathbf{E}$ \\
\hline \multicolumn{3}{|l|}{ Chenopodiaceae } \\
\hline \multicolumn{3}{|l|}{ Vitaceae } \\
\hline $\begin{array}{l}\text { Vitis vinifera L. (European wine grape, } \\
\text { Thompson Seedless) }\end{array}$ & 284 & $\mathbf{G}$ \\
\hline \multicolumn{3}{|l|}{ Rosaceae } \\
\hline Rosa multiflora Thunb. (multiflora rose) & 208 & G \\
\hline Prunus persica (L.) Butsch. (peach, Lovell) & 131 & $\mathbf{G}$ \\
\hline P. (Prunophora) americana L. (apricot) & 102 & G \\
\hline $\begin{array}{l}P . \text { persica (L.) Butsch. (peach, Nema- } \\
\text { gaard) }\end{array}$ & 58 & $\mathbf{P}$ \\
\hline P. mahaleb. L. (cherry, Mahaleb) & 289 & $\mathbf{G}$ \\
\hline Malus silvestris Mill. (common apple) & 122 & $\mathbf{G}$ \\
\hline Pyrus communis L. (pear) & 39 & $\mathbf{P}$ \\
\hline \multicolumn{3}{|l|}{ Juglandaceae } \\
\hline $\begin{array}{l}\text { Juglans californica Wats. (walnut, black } \\
\text { California) }\end{array}$ & 16 & $\mathbf{P}$ \\
\hline \multicolumn{3}{|l|}{ Compositae } \\
\hline Lactuca sativa L. (lettuce) & 441 & G \\
\hline Cruciferae & & \\
\hline $\begin{array}{l}\text { Brassica oleracea var. capitata C. (cabbage) } \\
\text { Fallow }\end{array}$ & 590 & G \\
\hline Fallow & 10 & \\
\hline
\end{tabular}

1 Length of experiment: 8 weeks.

2 Represents the means of 5 replicates. The original inoculum consisted of 100 specimens of all developmental stages.

Host ratings: $E=$ excellent; $G=\operatorname{good} ; P=$ poor; $N=$ nonhost.

- Best host available before the experiment, based on the literature. 
TABLE 6.-Plant species tested as potential hosts of T. allius ${ }^{1}$ at $\&$ different temperatures

\begin{tabular}{|c|c|c|c|}
\hline \multirow{2}{*}{ Plant species } & \multicolumn{2}{|c|}{ Nematode populations2 } & \multirow{2}{*}{$\begin{array}{c}\text { Host } \\
\text { ratings }\end{array}$} \\
\hline & $18-35^{\circ} \mathrm{C}$ & $24 \pm 2^{\circ} \mathrm{C}$ & \\
\hline \multicolumn{4}{|l|}{ Solanaceae } \\
\hline $\begin{array}{l}\text { Lycopersicon peruvianum (L.) Mill } \\
\text { Nicotiana glutinosa L. } \\
N \text {. tabacum var. xanthi-nc (glurk } \\
\text { tobacco) }\end{array}$ & $\begin{array}{l}2 \\
4 \\
0\end{array}$ & $\begin{array}{r}27 \\
4,950 \\
7,624\end{array}$ & $\begin{array}{l}\mathbf{P} \\
\mathbf{E} \\
\mathbf{E}\end{array}$ \\
\hline $\begin{array}{l}\text { N. tabacum var. turkish (turkish } \\
\text { tobacco) }\end{array}$ & $一$ & 4,790 & $\mathbf{E}$ \\
\hline Pelunia hybrida Vilm., (garden petunia) & - & 3,951 & $\mathbf{E}$ \\
\hline Datura stramonium L., (jimpsonweed) & 一 & 11 & $\bar{N}$ \\
\hline Solanum tuberosum L., (potato) & - & 943 & $\mathrm{G}$ \\
\hline \multicolumn{4}{|l|}{ Leguminosae } \\
\hline $\begin{array}{l}\text { Pisum sativum L., (garden pea, Progress } \\
\text { Imp. Lanthonian) }\end{array}$ & 2 & 2,336 & $\mathbf{E}$ \\
\hline Vicia faba L., (broad bean) & - & 24,408 & $\mathbf{E}$ \\
\hline Medicago sativa L. (alfalfa, Caliverde) & 0 & 313 & $\mathbf{G}$ \\
\hline $\begin{array}{l}\text { Trifolium repens } \mathrm{L} \text {. (white clover) } \\
\text { Vigna sinensis (Torner) Savi (cowpea, }\end{array}$ & 175 & 221 & $\mathbf{G}$ \\
\hline Blackeye 5) & & 83 & $\mathbf{P}$ \\
\hline $\begin{array}{l}\text { Lathyrus odoratus L. (sweetpea, Flori- } \\
\text { bunda mixed) }\end{array}$ & 624 & 12,560 & $\mathbf{E}$ \\
\hline Malvaceae & & & \\
\hline Gossypium hirsutum L. (upland cotton) & 649 & 3,771 & $\mathbf{E}$ \\
\hline \multicolumn{4}{|l|}{ Umbelliferae } \\
\hline $\begin{array}{l}\text { Apium graveolens } \mathrm{L} \text { var. dulce } \mathrm{DC} . \\
\text { (celery) }\end{array}$ & 一 & 1,496 & $\mathbf{E}$ \\
\hline \multicolumn{4}{|l|}{ Compositae } \\
\hline $\begin{array}{l}\text { Carthamus tinctorius L. (safflower, } \\
\text { Pacific 7) }\end{array}$ & 214 & 9,689 & $\mathbf{E}$ \\
\hline $\begin{array}{l}\text { Helianthus annuus L., (common sun- } \\
\text { flower) }\end{array}$ & 2 & 35,235 & $\mathbf{E}$ \\
\hline $\begin{array}{l}\text { Lactuca sativa L (lettuce, Early Curled } \\
\text { Simpson) }\end{array}$ & 38 & 22,806 & $\mathbf{E}$ \\
\hline \multicolumn{4}{|l|}{ Gramineae } \\
\hline $\begin{array}{l}\text { Zea mays var. saccharata (Sturtev.) } \\
\text { Bailey (sweet corn) }\end{array}$ & 26 & 2,738 & $\mathbf{E}$ \\
\hline Secale cereale L. (rye, Merced) & - & 1,406 & $\mathbf{E}$ \\
\hline $\begin{array}{l}\text { Triticum aestivum (L.) vulgare Vill. } \\
\text { (wheat) }\end{array}$ & - & 10,202 & $\mathbf{E}$ \\
\hline Avena sativa Cutigen (oats, Ventura) & - & 167 & $\mathbf{G}$ \\
\hline $\begin{array}{l}\text { Sorghum vulgare var. Sudanense (Piper) } \\
\text { Hitchc. (sudan grass) }\end{array}$ & - & 33,634 & $\mathbf{E}$ \\
\hline Liliaceae & & & \\
\hline $\begin{array}{l}\text { Allium cepa L., (onion, Stockton Yellow } \\
\text { Globe) }\end{array}$ & - & 86 & $\mathbf{P}$ \\
\hline A. cepa L., (onion, Sweet Spanish) & 266 & - & $\mathbf{G}$ \\
\hline
\end{tabular}


TABLE 6.-Continued

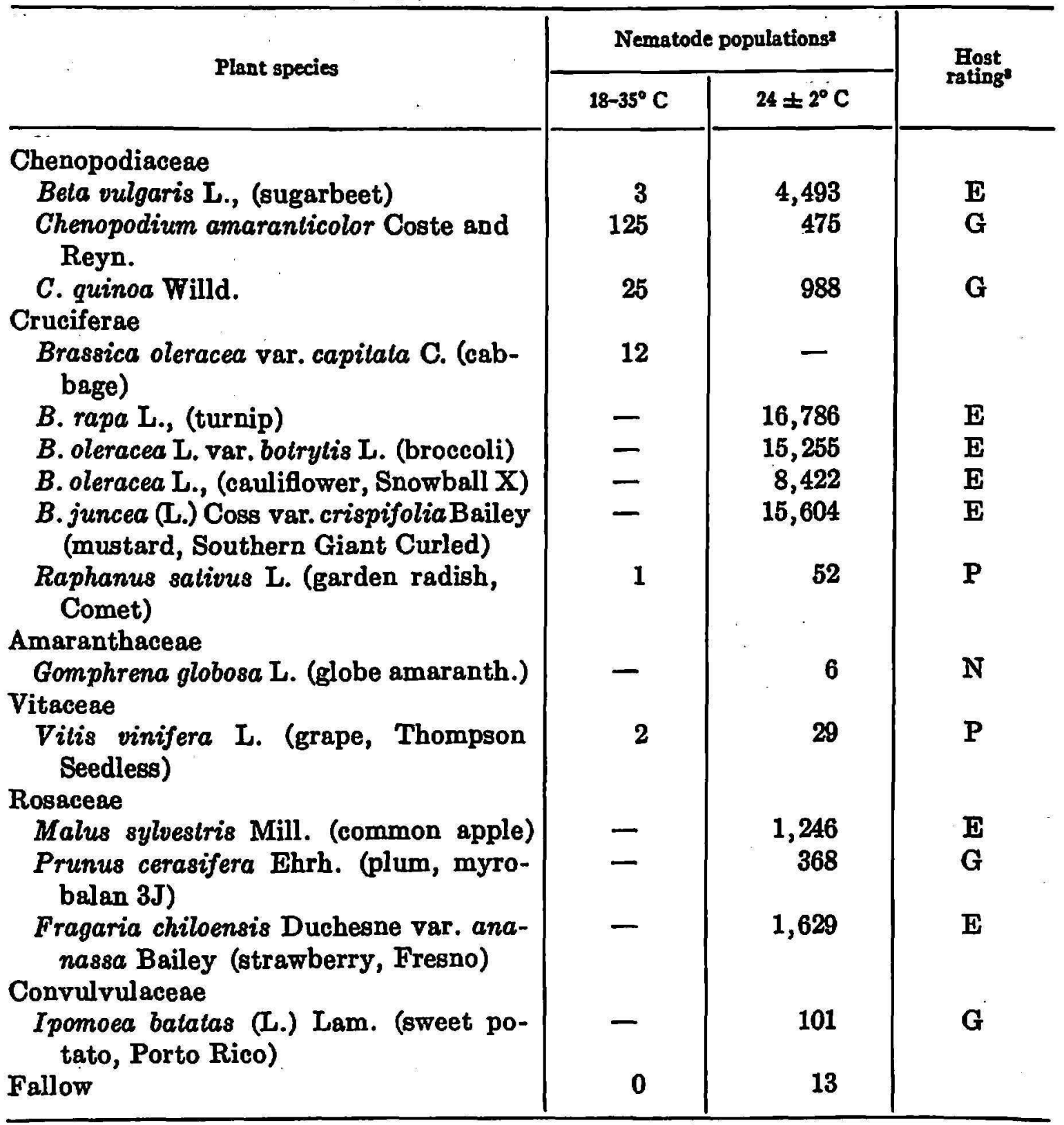

1 Length of experiment: 8 weeks.

${ }^{2}$ Mean nematode population in 5 replicates at $18^{\circ}-35^{\circ} \mathrm{C}$. or 4 replicates $24^{\circ} \pm 2^{\circ} \mathrm{C}$. The original inoculum consisted of 100 nematodes.

${ }^{3}$ Host ratings: $\mathrm{E}=$ excellent; $\mathrm{G}=$ good; $\mathrm{P}=$ poor; $\mathrm{N}=$ nonhost (based on $24^{\circ} \pm 2^{\circ} \mathrm{C}$. when applicable.

1 Symbols: $0=$ no nematodes; $-=$ not used at this temperature.

6 Best host available before experiment, according to the literature.

peach, apricot and rose were good hosts, while pear and Nemagaard peach were poor hosts.

The host range of $T$. allius was surprisingly wide. Among the hosts, sunflower, sudan grass, broad bean, and lettuce, in descending order were 
the best hosts. Eight more of the plants tested (table 4) proved to be good hosts, only five poor, e.g., Lycopersicon peruvianum, cowpea, onion, radish and grape. Only two plant species, jimsonweed, and globe amaranth, were not hosts of Jensen's stubby root nematode. Differences in host preferences of this species (tables 3,4 , and 5) and the previous two are pronounced, especially with reference to $L$. peruvianum, $N$. glutinosa, alfalfa, cowpea, and lettuce. Some of the factors affecting nematode reproduction had been studied before the last experiment, the results of which were employed to provide best conditions for nematode increase. At ambient temperatures (ranging from $18^{\circ}$ to $35^{\circ} \mathrm{C}$.) nematode populations were always very low and the nematode reproduced in only 5 of the 32 plant species tested.

\section{BIOLOGY OF $T$. CHRISTIEI AND T. ALLIOS}

Observations on egg laying, hatching, and early development of $T$. christiei showed the females never contained more than two eggs at one time. At $21^{\circ} \mathrm{C}$. or at room temperatures close to $21^{\circ} \mathrm{C}$., eggs were laid in a very short time in tap water, distilled water or 1-percent water agar. Ecdysis occurred 5 to 6 days later. Second-stage larvae were active for 7 days during which time they were not seen to feed on the alfalfa roots provided; later the larvae became inactive and died. Females in 1-percent water agar survived for $\mathbf{1 5}$ days but were not observed feeding. Those in water or in different concentrations of Hoagland's nutrient solution survived as long as the solution was changed twice a day.

Trichodorus allius females also laid eggs readily at $21^{\circ} \mathrm{C}$. or at room temperatures but the eggs did not hatch in water. Axenized and nonaxenized nematodes of this species survived for 5 days in 1.5-percent water agar with iron, Knop stock solution, and Berthelot stock added but did not lay eggs. One female was observed feeding on sweetpea roots 15 minutes after inoculation. Two other females remained feeding for two consecutive days, but died in the feeding area. The nematodes were successfully sterilized with Aretan for 12 to 18 hours, and remained active when a supply of air was provided in the tube. Sterilization did not seem to affect their activity to a great extent. No differences were observed in survival time between sterilized nematodes and those rinsed in sterile glass distilled water. Death of these populations after 5 days can not be explained, but $\mathrm{pH}$ and lack of oxygen could be possible causes of death. Observations on populations in a constant temperature water bath at $20^{\circ} \mathrm{C}$. and Glurk tobacco growing in a soil-coarse sand mixture (1:3) showed that development from second stage larvae to egg-laying females and from adults to fourth-stage larvae took place in 22 days. The time required to complete the entire life cycle was not studied. 


\section{DISCUSSION}

Soil type affected nematode reproduction. Trichodorus allius reproduced better in light soils, but sand alone was not beneficial for nematode reproduction which suggested that nutrients are needed in the media by the plant to support a good nematode population. Poor reproduction in pure potting soil may be due to a lack of aeration or impairment of movement due to reduced air spaces and permeability. The influence of soil type on plant-parasitic nematodes is a highly complex problem because physical and chemical factors vary so greatly between different localities (44). Hollis and Fielding (14) found in Louisiana that distribution of Trichodorus was independent of soil type. Trichodorus pachydermus is rare in clay soils and occurs most commonly in sandy soils in Holland whether in pasture, woodland, or cultivated and non-cultivated soils (38). Thomason (41) compared the development of $T$. christiei on sudan grass in three soil types and found while the population of this nematode increased most rapidly and reached the highest concentration in sandy loam survival was also lowest in this soil type.

Ecological factors other than soil type may have a direct effect on the increase of nematode populations. Temperature was a very important factor for the species of Trichodorus used in this investigation. Reproduction of $T$. christiei under a wide range of temperatures agrees with its reported distribution in the United States. It is widespread in the Southeastern States (39), and has been found as far north as Massachusetts (46). Rohde and Jenkins (34) reported the optimum temperature for development and size of both larvae and adults of T. christiei was $30^{\circ} \mathrm{C}$., and that the nematode did not reproduce below $21^{\circ} \mathrm{C}$. Malek, Jenkins, and Powers (26) found that optimum temperature for development of the species of Trichodorus in these experiments fell in the range of $15^{\circ}$ to $30^{\circ}$. C as suggested by Wallace (44) for phytoparasitic nematodes. The wide effective temperature range of $T$. christiei and $T$. porosus and the narrow range for $T$. allius probably accounts for the fact that the first two species survived and reproduced well under greenhouse ambient temperatures while $T$. allius seldom reproduced under these conditions. Cultures of T. allius had to be maintained at $21^{\circ} \mathrm{C}$. This nematode has been reported only from onion fields in Oregon (15) and found in fields in the Salinas valley of California.

Results reported here should not be interpreted as a direct function of temperature on the nematode alone because the host plant obviously was affected by temperature which may have an indirect effect on the nematode. Humidity, oxygen and carbon dioxide concentration, microorganisms, and $\mathrm{pH}$ also are altered at different temperatures and in turn may effect the nematodes. Godfrey (11) showed that gall development was affected by temperatures differently in different hosts. Krusberg (19) found that 
higher temperatures are required for development of Tylenchorhynchus claytoni on tobacco than on wheat. There were indications that interactions of temperature and host plant took place with T. allius, especially in sweetpea and cotton.

Population increases of $T$. christiei were greatly affected by fertilizer concentrations in the form of Hoagland's nutrient solution. Results with $T$. christiei agree with those of Kirkpatrick et al. (18) who found that fertilizer applications to avocado trees were consistently associated with a decrease in the average number of $T$. christiei per pint of soil.

Population increases with fertilizer concentration as high as 50 percent may be due to the increase in plant vigor, root development, and available nutrients for the nematode. Decreases in population levels while plant vigor increased, as found when Hoagland's nutrient solution alone was added, is not fully understood. There are some possible explanations such as high concentration of salts, $\mathrm{pH}$ of the fertilizer, oxygen and carbon dioxide, ion concentration, osmotic pressure, and host vigor and nutrition. Penetration of excised cucumber roots in pure culture by Meloidogyne incognita and subsequent larval development can be manipulated by regulating the nutrient constituents of the culture media $(24,25)$. This is much more difficult to measure in soil solutions, but Bird (5) observed that growth of Meloidogyne incognita generally was more rapid on tomato plants deficient in nitrogen, magnesium, potassium, and iron. Wallace (44) suggested the osmotic potentials should not be overlooked when chemical concentrations are involved in experiments. Loewenberg (20) showed survival of $M$. incognita in vitro to be dependent upon the mineral balance of the surrounding media. The nutritional status of the host may affect the ability of the nematode to penetrate and feed on the roots due to development of resistance or alterations of possible attractiveness of the host to the parasite. Attractiveness of roots to nematodes may increase with root growth (20) but a point may be reached when an excessive root system may be detrimental to the nematode. Plant roots may compete actively with the nematode for available oxygen in the soil and accumulation of carbon dioxide exuded by roots may affect the nematode. Bird ( 5$)$ suggests the root factors considered important in nematode attraction such as carbon dioxide output, root exudations, and electrical potentials vary under different environmental conditions.

Trichodorus allius reproduced better on virus-infected Glurk tobacco plants than on the virus-free plants. This reaction has not been reported for any other nematode vector. The virus may affect the host plant in such a way that it is more suitable for nematode feeding or the virus may provide the mechanism by which certain nutrients necessary for nematode reproduction become more available. 
Establishment of a parallel with some of the insect-transmitted viruses is pure speculation. Severin (87) found nine species of leaf hoppers able to complete their nymphal stages on celery or aster plants infected with California aster yellows, while the adults died shortly after being transferred to healthy plants. He interpreted these results as an indication that in some way the celery and aster plants were altered by the virus to make them a more suitable source of food. Kennedy (17) found sugar beet mosiac virus altered the physiology of host plants in such a manner that Aphis fabae produced more young aphids per mother on virus-infected leaves of all stages than on healthy leaves of comparable age. Maramorosch (27) reported the leafhopper Dalbulus maidis (Dehony and Wolcot), which acquires and retains aster yellow virus in its haemolymph but does not transmit it, survived for long periods on china aster, Callisterus chinensis, infected with the virus. The same leaf hopper is highly host-specific and breeds well only on maize, Zea mays, and teosinte, Euchlaena mexicana, but dies within 5 days on most other plants including healthy china aster (28). After the insects have survived for 7 days on virus-infected aster plants, they then are able to survive on healthy asters and other plants such as carrots and rye. It was suggested by some workers that aster is altered by the virus to make the plant more palatable for the leaf hopper, but Oreski and Maramorosch (31) found it was not food acceptability but food digestion that was altered in the corn leaf hoppers, after feeding on virus-infected plants.

No conclusions can be reached about the effect of plant viruses on nematodes until further investigations are carried out. Accumulated evidence suggests that relationships between insect and plant viruses form a symbiotic spectrum with mutual benefit at one end and lethal parasitism at the other (29). Apparent effects of CTRV on T. allius could be classified as beneficial (mutualism), and adults of $L$. elongatus which fail to transmit TBRV may be indicative of an adverse effect of the virus on the nematode (32). Loewenberg, Sullivan, and Schuster (21) reported the detrimental effects of a virus on larvae of Meloidogyne incognita incognita.

To store populations of $T$. allius in water it was necessary to use a humidity chamber. Also, large numbers would die in a short period of time if the nematodes were not removed from the Baermann funnel within 3 hours. Trichodorus christiei and T. porosus would remain active in the funnels for more than 24 hours. Van Gundy et al. (43) reported that $T$. christiei was sensitive to exposures of oxygen concentrations. Apparently, $T$. allius is more sensitive to oxygen depletion or carbon dioxide concentration but no controlled experiment was conducted in this respect.

Populations of $T$. christiei from spinach were affected by an unidentified condition which caused the cuticle to swell in the posterior part of the 
body. The swelling usually occurred on the ventral side a few microns from the anal opening, but varied in position and development in different nematodes. This condition may be detrimental to the nematode as most specimens appeared sluggish and transparent but rate of reproduction was not affected. Loewenberg, Sullivan, and Schuster (21) suggested a virus may infect Meloidogyne incognita incognita larvae, causing them to be sluggish and incapable of producing galls in a host. Adams and Eichenmuller (1) suggested that $X$. americanum was infected by a bacterium but the evidence was not conclusive. The nature of the swelling in T. christiei remains unknown but it is possible that this condition may be caused by either of the above entities.

The three species of Trichodorus appear to be polyphagous because 90 to 95 percent of the plants tested were hosts for $T$. christiei, $T$. porosus, and $T$. allius. Host preferences of the Riverside isolate of $T_{\text {: }}$ chrisitiei are somewhat different from an isolate from Florida used by Rohde and Jenkins (33) and Coursen, Rohde and Jenkins (10). These variations in host range are similar to specificity of host preferences among isolates or populations of the nematode as found in several other plant parasitic species. Results suggest the existence of physiological races; however, conditions under which the experiments were conducted, plant variety and nematode recovery may be factors responsible for some of the variation. Plant species such as Lycopersicon peruvianum, cabbage, tomato, cowpea, and lettuce, all excellent hosts for $T$. christiei, were only poor to good hosts of T. porosus. Trichodorus allius, previously reported only from onions in Oregon (15), had a very wide host range at $24 \pm 2^{\circ} \mathrm{C}$. in a coarse sand-soil mixture (2:1), but populations increased in only five plant species in fluctuating temperatures $\left(15^{\circ}-35^{\circ} \mathrm{C}\right.$.) in pure greenhouse soil. Among many others, Lycopersicon peruvianum, oats, cowpea, sweet corn, alfalfa, and Chenopodium amaranticolor, which are excellent hosts for $T$. christiei, supported low populations of $T$. allius, whereas Glurk tobacco and Petunia hydrida, which are nonhosts for T. christiei, were excellent hosts for T. allius.

\section{SUMMARY}

Populations of T. allius increased to levels nine times higher in Glurk tobacco plants infected with California tobacco rattle virus than in healthy plants of the same variety and age. Populations of $T$. christiei increased with applications of Hoagland's nutrient solution diluted up to 50-percent concentration, whereas population densities were low at the highest concentration (100 percent), and in water alone. Trichodorus allius did not seem to be affected to a large extent by similar applications of Hoagland's nutrient solution. Soil type influenced populations of $T$. allius; lighter 
soils were conducive to development of higher populations while soil, coarse sand, and white quartz sand used separately were not favorable for reproduction.

Temperature proved to be one of the most important ecological factors in nematode reproduction. The optimum temperatures for the reproduction of each species was as follows: T. christiei, $16^{\circ}$ to $24^{\circ} \mathrm{C}$.; T. porosus, $24^{\circ} \mathrm{C}$.; and. $T$ allius, $21^{\circ}$ to $24^{\circ} \mathrm{C}$. Extremes of temperatures at which the different species could reproduce also varied.

Populations of $T$. christiei were affected by an undetermined disease or condition which seemed to slow movement but did not have any apparent effect on rate of reproduction.

Host ranges of three species of Trichodorus were studied. All three nematode species seemed to be polyphagous because 90 percent, 90 percent and 95 percent of the plant species tested were hosts of $T$. christiei, T. porosus, and $T$. allius, respectively. Twenty-five plant species were tested for $T$. porosus, 50 for $T$. christiei and 38 for $T$. allius.

A method is described for keeping populations of T. allius alive in water for extended periods of time.

\section{RESUMEN}

Las poblaciones del nematodo Trichodorus allius aumentaron a unos niveles nueve veces más altos en las plantas de tabaco infectadas por el virus "California tobacco rattle" que en las saludables. El T. christiei se reprodujo más rápidamente en aquellas plantas que recibieron aplicaciones de la solución nutritiva de Hoagland al 50 por ciento, mientras que la reproducción en agua o la solución sin diluir fue mucho más reducida. $T$. allius no respondió de la misma manera a las aplicaciones similares de la solución. La misma especie produjo grandes poblaciones en aquellos suelos livianos que contenían un porcentaje alto de arena, mientras que ninguno de los tres tipos de suelos usados para hacer las mezclas (suelo corriente, arena blanca, arena gruesa) fueron favorables por separado para la reproducción de los nematodos.

Uno de los factores ecológicos más importantes en cuanto a la reproducción de todas las especies usadas en nuestros estudios fue la temperatura del suelo. La temperatura óptima para la reproducción de las tres especies fue como sigue: $T$. christiei, $16^{\circ}-24^{\circ} \mathrm{C}$.; $T$. porosus, $24^{\circ}$ C. y $T$. allius, $21^{\circ}-$ $24^{\circ} \mathrm{C}$. Hubo también variaciones marcadas en los extremos de temperatura, en la cual se reprodujeron las tres especies mencionadas.

Un gran porcentaje de los miembros de una población de $T$. christiei fue afectado por una condición de naturaleza desconocida que aparentemente afectó la habilidad de movimiento del nematodo, pero no su capacidad reproductiva. 
Se llevaron a cabo estudios intensivos de las plantas hospedadoras de las tres especies del nematodo. Las tres especies parecen ser polifagas, ya que un 90 por ciento, 90 por ciento y 95 por ciento de las plantas resultaron ser hospedadoras de $T$. christiei, $T$. porosus y $T$. allius, respectivamente. Se usaron 25 especies de plantas con el $T$. porosus, y 50 y 38 con el $T$. christiei y el $T$. allius, respectivamente.

Se describe un nuevo método para mantener las poblaciones de $T$. allius vivas en agua durante largos períodos.

\section{LITERATURE CITED}

1. Adams, R. E., and Eichenmuller, J. J., A bacterial infection of Xiphinema americanum, Phytopathology 63 (7): 745, 1963.

2. Allen, M. W., A review of the nematode genus Trichodorus with description of ten new species, Nematologica \& (1): 32-62, 1957.

3. Anonymous, Index of Plant Diseases in the United States. Agriculture Handbook No. 165, ARS, USDA, Washington, D.C., 531 pp., 1960.

4. Bailey, L. H., Manual of Cultivated Plants, The Macmillan Co., N. Y., 1,116 pp., 1949.

5. Bird, A. F., The effect of some single element deficiencies on the growth of Meloidogyne javanica, Nematologica 5 (2): 78-85, 1959.

6. Bird, G. W., and Mai, W. M., Plant species in relation to morphometric variation of the New York population of Trichodorus christiei (Abst.), Nematologica 11 (1): 34, 1964.

7. Christie, J. R., Plant Nematodes, Their Bionomics and Control, The H. \& W. B. Drew Co., Jacksonville, Fla., 256 pp., 1959.

8. Christie, J. R., and Perry, V. G., A root disease of plants caused by a nematode of the genus Trichodorus, Science 118: 491-94, 1951.

9. Cobb, N. A., New nematode genera found inhabiting fresh water and nonbrakish soils. J. Wash. Acad. Sci. 3 (16): 432-44, 1913.

10. Coursen, B. W., Rhode, R. A., and Jenkins, W. R., Additions to the host lists of the nematodes Paratylenchus projectus and Trichodorus christiei, Plant Dis. Rpt. 48 (4): 456-60, 1958.

11. Godfrey, G. H., Effect of temperature and moisture on nematode root knot, $J$. Agric. Res. 38 (3): 223-54, 1926.

12. Hewitt, Wm. B., Raski, D. J., and Goheen, A. C., Nematode vector of soilborne fanleaf virus of grapevines, Phytopathology 48 (11): 586-95, 1958.

13. Hoff, J. K., and Mai, W. F., Pathogenicity of the stubby root nematode to onion, Plant Dis. Reptr. 46 (1): 24, 1962.

14. Hollis, J. P., and Fielding, M. J., Population behavior of plant parasitic nematodes in soil fumigation experiments, Bull. 515, La. State Univ. Agr. Exp. Sta., 1958.

15. Jensen, H. J., Trichodorus allius, a new species of stubby-root nematode from Oregon (Nemata: Dorylimoidea), Helminth. Soc. Wash. Proc. 30 (1): 157-59, 1963.

16. Jensen, H. J., and Konicek, D. E., Stubby-root nematodes causes a serious decline of dry onion production in Oregon, Phytopathology 52 (4): 362, 1962.

17. Kennedy, J. S., Benefits to aphids from feeding on galled and virus-infected leaves, Nature 168: 825-26, 1951.

18. Kirkpatrick, J. D., Van Gundy, J. D., and Mai, W. F., Interrelationships of 
plant nutrition, growth, and parasitic nematodes, Plant Analysis and Fertilizer Problems 4: 189-225, 1964.

19. Krusberg, L. R., Investigations on the life cycle, reproduction, feeding habits and host range of Tylenchorhynchus claytoni Steiner, Nematologica 4: 187-97, 1959.

20. Loewenberg, J. R., Gall induction by Meloidogyne incognita incognita by surface feeding and factors affecting the behavior pattern of second stage larvae, Phytopathology, 50 (4): 322-23, 1960.

21. Loewenberg, J. R., Sullivan, T., and Schuster, M. L., A virus disease of Meloidogyne incognita incognita, the southern root knot nematode, Nature 184: $1886,1959$.

22. Lownsbery, B. F., and Lownsbery, J. W., A procedure for testing the sterility of large numbers of nematodes after treatment with various sterilants, Plant Dis. Rptr. 40 (11): 989-990, 1956.

23. Lownsbery, B. F., and Tarjan, A. C., Pathogenicity of some plant-parasitic nematodes from Florida soils. II. Reaction of celery seedlings to a plantparasitic nematode complex, Plant Dis. Rptr. $\$ 5$ (9): 403-04, 1951.

24. McClure, M. A., and Viglierchio, D. R., Penetration of Meloidogyne incognita in relation to growth and nutrition of sterile, excised cucumber roots, Nematologica 18: 237-47, 1966.

25. - The influence of host penetration and intensity of infection on the sex ratio and development of Meloidogyne incognita on sterile agar cultures of excised cucumber roots, Nematologica 18: 248-58, 1966.

26. Malek, W. R., Jenkins, W. R., and Powers, E. M., Effect of temperature on growth and reproduction of Criconemoides curvatum and Trichodorus christiei (Abst.), Nematologica 11: 42, 1965.

27. Maramorosch, K., Healthy and yellows aster as food plants for corn leafhoppers, Abst. Proc. 7th int. Cong. Microbiol., Stockholm, p. 260, 1958.

28. - Beneficial effect of virus-disease plants on non-vector insects, Plantenziekten 64: 383-91, 1958.

29. - Virus-vector relationships: vectors of circulative and propagative viruses. Plant Virology, Univ. of Fla. Press, Gainesville, Fla., pp. 175-93, 1964.

30. Mountain, W. B., Pathogenesis by soil nematodes; Ecology of Soil-borne Plant Pathogens. Univ. of Calif. Press, Berkeley, Calif., pp. 285-301, 1965.

31. Oreski, S. W., and Maramorosch, $\mathbf{K}$., The feeding of normal and aster yellowsinoculated corn leafhoppers, Phytopathology 68: 1219, 1962.

32. Raski, D. J., and Hewitt, Wm. B., Plant-parasitic nematodes as vectors of plant viruses, Phytopathology 68: 39-47, 1963.

33. Rhode, R. A., and Jenkins, W. R., Host range of a species of Trichodorus and its host-parasite relationships on tomatoes, Phytopathology 47: 295-98, 1957.

34. - Effect of temperature on the life cycle of stubby root nematodes, Phytopathology 47 (1): 29, 1957.

35. Rhoades, H. L., Effects of sting and stubby-root nematodes on St. Augustine grass, Plant Dis. Rptr. 46: 424-27, 1962.

36. - Parasitism and pathogenicity of Trichodorus proximus to St. Augustine grass, Plant Dis. Rptr. 49 (3): 259-62, 1965.

37. Severin, H. H. P., Longevity or life histories of leafhoppers species on virusinfected and on healthy plants, Hilgardia 17: 121-33, 1946.

38. Sol, H. H., and Seinhorst, J. W., The transmission of rattle virus by Trichodorus pachydermus, Tijdschr. Plantenzielten 67: 307-11, 1961. 
39. Standifer, M. S., and Perry, V. G., Some effects of sting and stubby root nematodes on grapefruit roots, Phytopathology 50: 152-56, 1960.

40. Swank, G., and Perry, V. G., Control of disease in celery seedbeds with methyl bromide, Univ. of Fla. Exp. Sta. Circular 555: 1-7, 1953.

41. Thomason, I. J., Influence of soil texture on development of the stubby root nematode, Phytopathology 49 (9): 552, 1959.

42. Thomason, I. J., and Sher, S. A., Influence of the stubby root nematode on growth of alfalfa, Phytopathology 47 (3): 159-61, 1957.

43. Van Gundy, S. D., et al., Influence of oxygen supply on survival of plant parasitic nematodes in soil, Phytopathology 68 (7): 628-32, 1962.

44. Wallace, H. R., The Biology of Plant Parasitic Nematodes, William Clawes and Sons, Ltd., London, Eng., 280 pp., 1963.

45. Zuckerman, B. M., Parasitism and pathogenesis of the cultivated cranberry by some nematodes, Nematologica 6: 135-43, 1961.

46. - Parasitism and pathogenesis of the cultivated highbush blueberry bylt the stubby root nematode, Phytopathology 68 (10): 1,017-19, 1962. 